\title{
Pelatihan Seni Pertunjukan Sastra Lisan Lampung Kias bagi Muli Mekhanai Desa Kunjir Kabupaten Lampung Selatan
}

\author{
Farida Ariyani'1, I Wayan Mustika', Eka Sofia Agustina², Deris Astriawan² \\ ${ }^{1}$ Pendidikan Bahasa dan Kebudayaan Lampung, Universitas Lampung, Bandar Lampung, 35145, Lampung, \\ Indonesia \\ ${ }^{2}$ Pendidikan Bahasa Lampung, Universitas Lampung, Bandar Lampung, 35145, Lampung, Indonesia
}

\begin{abstract}
Abstrak.
Pengabdian kepada masyarakat ini merupakan upaya dalam rangka pengembangan dan pelestarian sastra lisan Lampung khususnya kias. Tujuan pengabdian kepada masyarakat ini adalah muli mekhanai Desa Kunjir diharapkan mampu mengolah, mengembangkan, dan mengekspresikan sebuah sajian sastra lisan Lampung kias menjadi sebuah seni pertunjukan yang menarik. Kegiatan pengabdian ini dilaksanakan di Kabupaten Lampung Selatan. Hasil yang diharapkan melalui pengabdian ini adalah diharapkan muli mekhanai mampu menjadi garda terdepan dalam rangka pengembangan dan pelestarian sastra lisan Lampung kias. Selanjutnya, pelatihan seni pertunjukan sastra lisan Lampung kias ini akan menerapkan pelatihan aktif dimana seluruh peserta bereksplorasi melalui pengalamannya sehingga tujuan yang telah direncanakan dapat diperoleh secara optimal. Metode yang digunakan dalam pelatihan ini adalah ceramah, tanya jawab, diskusi, demonstrasi, dan evaluasi. Jumlah peserta pelatihan ini sebanyak 25 orang yang tergabung dalam Muli Mekhanai Desa Kunjir Kabupaten Lampung Selatan. Keberhasilan kegiatan ini diukur dari proses maupun hasil pelatihan. Keberhasilan proses diukur dengan melakukan observasi terhadap beberapa aspek seperti keaktifan, ketekunan, kerjasama, dan tanggung jawab. Penilaian unjuk kerja dilakukan ketika peserta pelatihan secara individu maupun berkelompok. Evaluasi terhadap hasil kegiatan diukur berdasarkan berdasarkan penguasaan materi pelatihan baik yang meliputi konsep maupun praktik sastra lisan sebagai bagian dari seni tradisi masyarakat.
\end{abstract}

Keywords.

Seni Pertunjukan, Sastra Lisan, Kias.

\section{PENDAHULUAN}

Sastra yang merupakan hasil kebudayaan turun-temurun suatu daerah mempunyai nilainilai luhur yang perlu dikembangkan dan dimanfaatkan sebagai usaha menangkal efek negatif globalisasi. Sastra adalah bagian dari kebudayaan yang tumbuh dan berkembang di tengah-tengah masyarakat [1-2]. Salah satu unsur yang menjadi kekakayaan budaya di

\section{* Corresponding author: dulifarida@gmail.com}

Received 14 October 2021; Received in revised form 29 October 2021; Accepted 30 October 2021 
Lampung yakni sastra lisan. Sama halnya dengan yang lain, sastra lisan Lampung juga merupakan representasi dari pikiran, perilaku, kebiasaan, dan kehidupan dalam menghayati alam sekitar dan karakter masyarakat Lampung. Seiring berjalannya waktu, sastra lisan Lampung mulai dilupakan dan dimarjinalkan karna pengaruh yang besar dari kehidupan modernisasi dan kemajuan IPTEKS secara global.

Dalam kehidupan sehari-hari, jenis sastra lisan biasanya dituturkan oleh seorang ibu kepada anaknya, seorang tukang cerita pada para pendengarnya, guru pada para muridnya, ataupun antarsesama anggota masyarakat. Salah satu yang menjadi faktor terjadinya pergeseran pelestarian sastra lisan yakni sastra lisan kebanyakan dituturkan oleh generasi tua yang semakin hari semakin sedikit jumlahnya dikarenakan minimnya upaya regenerasi yang dilakukan oleh generasi muda. Hal ini dikarenakan, kalangan generasi muda menganggap penyajian sastra lisan Lampung kurang menarik dan tidak mengikuti perkembangan zamandan teknologi yang semakin maju, sehingga kalangan muda enggan belajar dan menuturkan sastra lisan karna terkesan ketinggalan zaman (kuno). Sedangkan, generasi muda memegang peran yang vital untuk kelangsungan sastra lisan yang ada di Lampung. Peran penting untuk melestarikan budaya dan sastra lisan Lampung tersebut harus direvitalisasi sedini mungkin untuk meminimalisir potensi punahnya sastra lisan tersebut.

Seiring mengikuti perkembangan zaman yang semakin maju, jika tradisi lokal dimodifikasi sedemikian rupa sehingga menjadi seni pertunjukan yang menarik dengan tidak meninggalkan unsur dari tradisi itu sendiri, pengembangan sastra lisan Lampung yang dikombinasikan dengan seni pertunjukan diharapkan dapat menghasilkan sebuah sajian pertunjukan yang dapat diterima oleh masyarakat luas dan membuat kalangan muda termotivasi dan percayadiri dalam pengembangkan dan menuturkan sastra lisan yang sudah diturunkan secara turun-temurun dari zaman dahulu.

Desa Kunjir merupakan salah satu wilayah di Kabupaten Lampung Selatan yang ditempati oleh masyarakat suku Lampung. Sastra lisan Lampung yang masih berkembang di masyarakat Desa Kunjir salah satunya yakni Kias. Menurut Sanusi (1999) Kias merupakan adalah puisi tradisi Lampung yang lazim digunakan sebagai pengantar acara adat, pemberian gelar atau adok, pelengkap acara tarian adat (cangget), pelengkap acara muda mudi (nyambai, miyah damagh, atau kedayek) [3]. Kias tumbuh dan berkembang dalam masyarakat dari mulut ke mulut atau secara lisan. Ada beberapa aspek yang terkait dengan kias, yakni orang yang berkias, orang yang bermain musik untuk mengiringi kias. Kias terdiri atas sejumlah bait dan setiap bait terdiri dari empat atau enam baris tergantung dari kebutuhan banyak atau sedikitnya pesan yang ingin disampaikan. Jika dilihat secara global, struktur kias digolongkan ke dalam puisi tradisional berbentuk syair. Kias tidak mempunyai sampiran, semua baris dalam setiap bait merupakan isi. Kias memiliki rima yang berbeda dengan syair, rima pada kias secara umum berpola abab, abcabc. Kias berisi nasihat, pesan kebaikan, ajaran agama, perjalanan hidup, kisah kesedihan, dan sebagainya.

Seiring dengan perkembangan zaman, kegiatan bersastra lisan kias mulai ditiggalkan oleh masyarakat Desa Kunjir. Hal ini disebabkan oleh kurang aktifnya muli mekhanai sebagai bagian dari masyarakat Desa Kunjir dalam mempelajari kias dan menggunakannya dalam setiap kegiatan adat. Tidak adanya pengajar yang bisa mengajarkan sastra lisan kias pada generasi muda turut menjadi faktor penghambat keberlangsungan sastra lisan kias di Desa Kunjir. Eksistensi sastra Lisan kias juga tergerus oleh dampak terjadinya Tsunami pada bulan Desember tahun 2018 yang memungkinkan masyarakat kehilangan motivasi serta catatan-catatan tentang sastra lisan Kias.

Berdasarkan pemaparan di atas, situasi terhadap perkembangan sastra lisan Lampung 
kias dianggap cukup mempriatinkan dan dinilai sangat penting untuk dilakukan revitalisasi melalui kegiatan pengabdian kepada masyarakat. Pengabdian ini dilakukan agar generasi muda khususnya muli mekhanai Desa Kunjir mampu menjadi lokomotor pelestarian sastra lisan kias yang merupakan kearifan lokal turun-temurun masyarakat Lampung pada umumnya dan Kabupaten Lampung Selatan pada khususnya.

\section{METODE}

Pelaksanaan pemecahan masalah yang telah diuraikan sebelumnya, dilakukan dalam bentuk kegiatan pelatihan. Sebelum pelatihan ini dilaksanakan, kami informasikan terlebih dahulu kepada kepala muli mekhanai Desa Kunjir bahwa LPPM Unila melalui tim pengabdian akan mengadakan pelatihan tentang seni pertunjukan sastra lisan Lampung kias. Untuk itu, kepala muli mekhanai diharapkan dapat mendata seluruh seluruh pemudapemudi di sekitar lokasi pengabdian yang akan dikirim mengikuti pelatihan ini. Peserta dalam pelatihan ini adalah 25 orang. Kegiatan ini akan dilaksanakan di Desa Kunjir Kabupaten Lampung Selatan selama dua hari.

Selanjutnya, pelatihan seni pertunjukan sastra lisan Lampung kias ini akan menerapkan pelatihan aktif dimana seluruh peserta bereksplorasi melalui pengalamannya sehingga tujuan yang telah direncanakan dapat diperoleh secara optimal. Metode yang digunakan dalam pelatihan ini adalah ceramah, tanya jawab, diskusi, demonstrasi, dan evaluasi.

\section{HASIL DAN PEMBAHASAN}

Peserta pelatihan adalah Muli Mekhanai di Desa Kunjir Kabupaten Lampung Selatan. Secara keseluruhan, peserta pelatihan berjumlah 25 orang yang terdiri dari 13 laki-laki dan 12 perempuan. Perhatikan tabel berikut.

Tabel 1. Distribusi Peserta Pelatihan

\begin{tabular}{llcccc}
\hline & & Frequency & Percent & Valid Percent & Cumulative Percent \\
\hline \multirow{3}{*}{ Valid } & Laki-laki & 13 & 52 & 52 & 52 \\
& Perempuan & 12 & 48 & 48 & 100.0 \\
& Total & 25 & 100.0 & 100.0 & \\
\hline
\end{tabular}

Antusias terhadap kegiatan ini sangatlah tinggi, hal tersebut dibuktikan dengan banyaknya Muli Mekhanai yang igin ikut menjadi peserta dalam pelatihan. Akan tetapi, kegiatan pelatihan ini menetapkan protokol kesehatan sehingga menyebabkan adanya pembatasan jarak antara satu dengan yang lain oleh sebab itu peserta hanya dibatasi 25 orang. Pada seluruh proses rangkaian kegiatan ini seluruh peserta dan panitia yang terlibat diwajibkan untuk mematuhi protokol kesehatan yang ada.

Setelah dilakukan pembukaan, para narasumber secara bergiliran memperkenalkan diri dan dilanjutkan dengan memberikan materi pelatihan sesuai dengan topik masing-masing. Adapun secara garis besar materi pelatihan tersebut menyangkut tentang seni pertunjukan sastra lisan Kias bagi Muli Mekhanai di Desa Kunjir Kabupaten Lampung Selatan. 


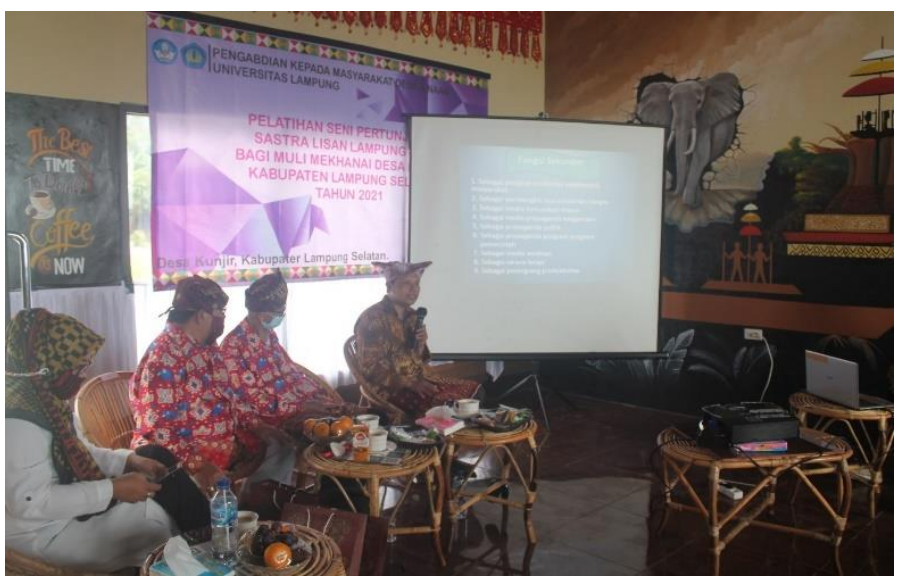

Gambar 1. Penyampaian Materi oleh Tim PKM

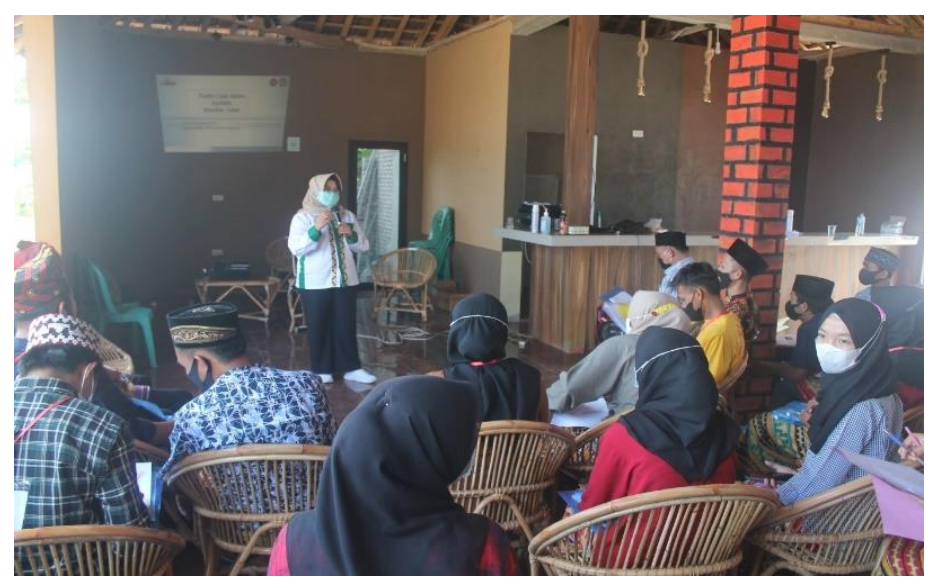

Gambar 2. Penyampaian Materi oleh Tim PKM

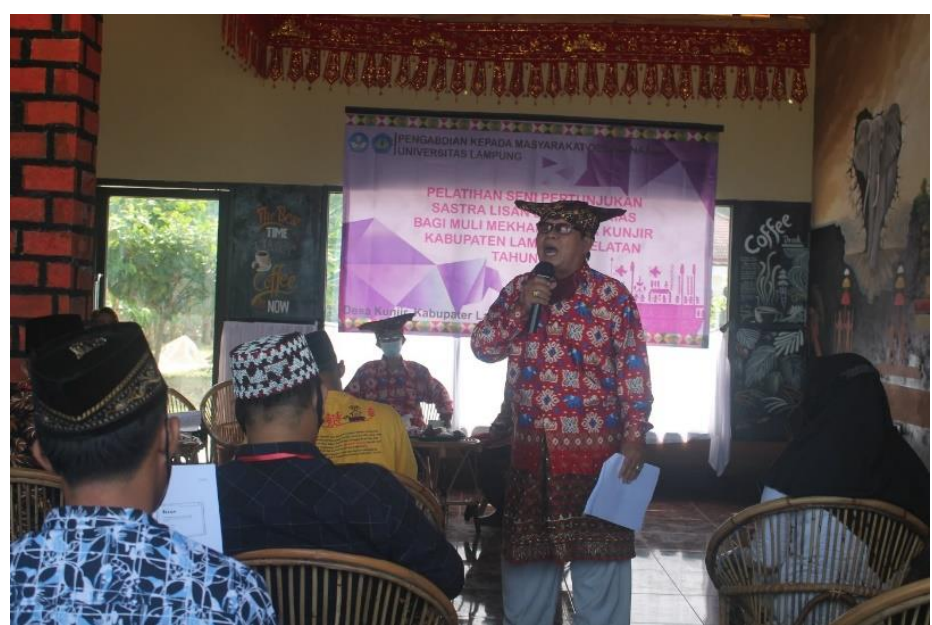

Gambar 3. Penyampaian Materi oleh Narasumber Lokal

Pada hari pertama pelatihan difokuskan pada penyampaian materi dari seluruh pemateri yang ada. Kemudian pada sesi terakhir di hari pertama seluruh peserta diberikan tugas untuk membentuk kelompok. Pada proses tersebut seluruh peserta dibagi ke dalam 5 kelompok dengan masing-masing anggota kelompok berjumlah 5 orang. Selanjutnya seluruh kelompok diwajibkan untuk membuat susunan bait sastra lisan Kias untuk dan kemudian ditampilkan pada hari kedua. 
Pada hari kedua, kegiatan pelatihan difokuskan pada unjuk kerja yang dilaksanakan oleh seluruh penampilan kelompok dan dinilai langsung oleh para pemateri. Pada penampilan tersebut seluruh kelompok diberikan kebebasan untuk mengonsep penampilan masingmasing sesuai dengan kesepakatan kelompok. Seluruh kelompok juga diperkenankan untuk memakai berbagai alat musik yang telah disiapkan oleh panitia. Beberapa alat musik tersebut dijadikan sebagai pengiring dalam penampilan pembacaan Kias agar dapat menjadi sebuah seni pertunjukan yang menarik. Perhatikan gambar berikut.

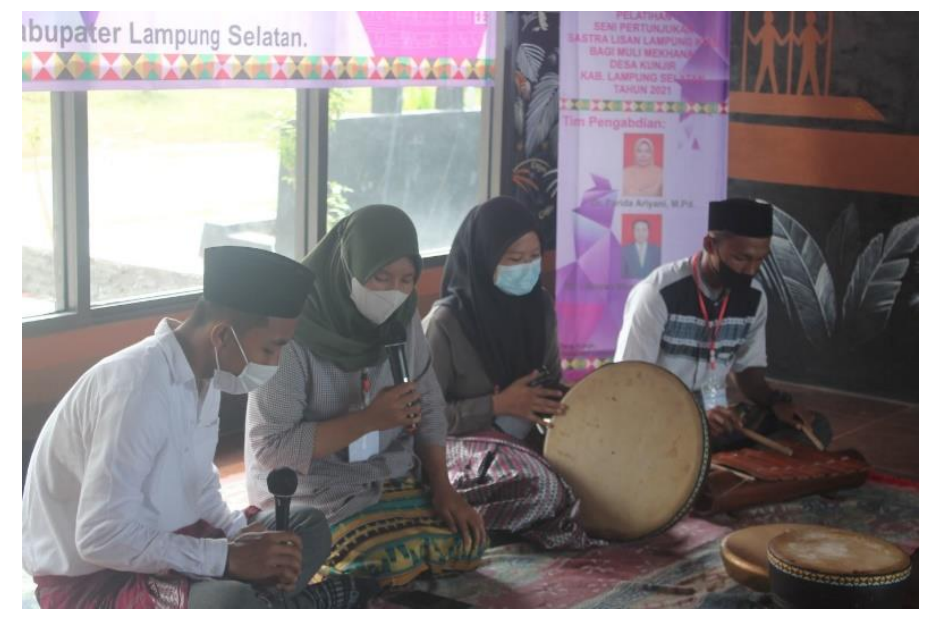

Gambar 4. Penampilan Pembacaan Kias oleh Peserta

Berdasarkan hasil penampilan kelompok, diperoleh simpulan bahwa seluruh kelompok telah mampu mengimplementasikan materi yang didapat pada saat pelatihan hari pertama. Hanya saja tetap ada beberapa catatan perbaikan untuk dipelajari oleh masing-masing kelompok. Setelah proses penampilan dan penilaian berlangsung diperoleh tiga kelompok terbaik. Kelompok tersebut dinilai cukup berhasil dalam mengemas dalam bentuk seni pertunjukan sebuah sastra lisan Kias. Keharmonisan antara kelima aspek penilaian tersebut yang kemudian menjadi dasar memilih kelompok-kelompok terbaik. Selain itu, bait-bait sastra yang mereka susun telah sesuai dengan kaidah yang berlaku.

Beberapa teks sastra yang telah dihasilkan oleh para peserta pelatihan bersifat sangat variatif sesuai dengan karakteristik masing-masing sesuai dengan tema sastra lisan yang dibawakan. Adapun beberapa tema yang diusung yakni diantaranya percintaan, harapan, nasihat, rasa kerinduan, dan kesedihan. Tema-tema tersebut dikemas menjadi sebuah seni pertunjukan yang relevan dengan alur cerita yang terkandung di dalam bait-bait sastra lisan yang telah disusun. Harmonisasi antara kandungan teks sastra lisan Kias dengan iringan alat musik yang ada semakin menambah hidup suasana pelatihan. Seluruh peserta terlihat sangat menikmati dan menghayati setiap penampilannya.

Pada pengabdian ini selain mengambil data sastra lisan hasil karya para peserta pelatihan, tim pengabdian juga menghimpun data angket yang disebarkan kepada seluruh peserta pelatihan. Angket tersebut terdiri atas angket materi pelatihan yang berisi pernyataan dalam menyikapi kondisi terkini peserta pelatihan dan angket evaluasi penyelenggaraan yang berisi evaluasi penyelenggaraan kegiatan pengabdian baik dari sisi acara maupun juga sarana dan prasarana pendukung kegiatan. Pengisian angket materi pelatihan dilakukan sesudah kegiatan pemaparan materi berlangsung. Sedangkan pengisian angket evaluasi penyelenggaraan dilakukan setelah seluruh kegiatan pengabdian selesai dilaksanakan.

Angket materi pelatihan bertujuan untuk mengetahui potret terkini mengenai pemahaman dasar para peserta dan dan kondisi mereka dalam menyikapi beberapa hal yang berkaitan 
dengan sastra lisan Kias di Desa Kunjir maupun pengembangan seni, bahasa, dan budaya secara umum. Di sisi lain, angket evaluasi penyelenggaraan bertujuan untuk melihat seberapa besar kebermanfaatan dan kesuksesan penyelenggaraan kegiatan pengabdian. Selain itu, angket tersebut digunakan untuk mengecek sejauh mana indikator ketercapaian proses pelaksanaan kegiatan berjalan sesuai dengan rencana awal. Perhatikan gambar berikut.

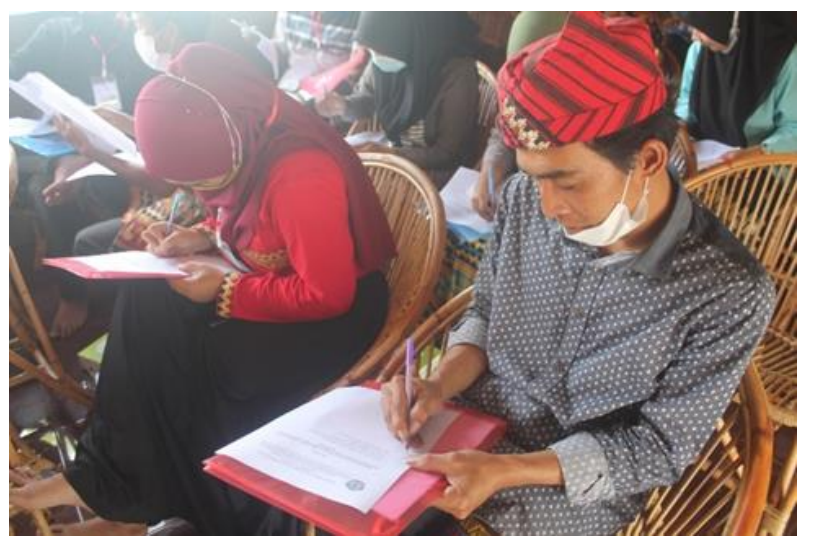

Gambar 5. Pengisian Angket oleh Peserta Pengabdian

Seluruh data yang diperoleh melalui angket tersebut akan dijadikan sebagai bahan evaluasi dan menjaring masukan dari peserta pengabdian untuk dijadikan rencana tindak lanjut pada kegiatan-kegiatan pengabdian kepada masyarakat di tahun berikutnya. Adapun berdasarkan hasil analisis angket materi pelatihan yang telah disebar, diperoleh data sebagai berikut.

Tabel 2. Angket Pengabdian

\begin{tabular}{|c|c|c|c|c|c|c|}
\hline No. & Pernyataan & SS & $S$ & $\mathbf{R R}$ & TS & STS \\
\hline 1. & $\begin{array}{l}\text { Sebagai orang Lampung penting bagi saya untuk } \\
\text { mengetahui sastra lisan Lampung }\end{array}$ & 15 & 10 & - & - & - \\
\hline 2. & $\begin{array}{l}\text { Sastra lisan Lampung merupakan simbol jati diri masyarakat } \\
\text { Lampung }\end{array}$ & 14 & 11 & - & - & - \\
\hline 3. & $\begin{array}{l}\text { Saya tidak bertanggungjawab untuk melestarikan sastra } \\
\text { lisan Lampung }\end{array}$ & - & 2 & - & 9 & 14 \\
\hline 4. & $\begin{array}{l}\text { Sebagai orang Lampung merupakan sebuah keharusan } \\
\text { untuk mengenal sastra lisan Lampung }\end{array}$ & 14 & 11 & - & - & - \\
\hline 5 & $\begin{array}{l}\text { Saya malu menampilkan sastra lisan Lampung di depan } \\
\text { umum }\end{array}$ & - & - & 7 & 8 & 9 \\
\hline 6. & $\begin{array}{l}\text { Sebagai seorang milenial, saya lebih tertarik melihat } \\
\text { kesenian modern yang menjadi trend terkini }\end{array}$ & 1 & 6 & 3 & 9 & 1 \\
\hline 7. & $\begin{array}{l}\text { Di lingkungan Desa Kunjir, sastra lisan Lampung masih } \\
\text { digunakan }\end{array}$ & 2 & 5 & 6 & 5 & 2 \\
\hline 8. & $\begin{array}{l}\text { Saya kurang mengenal sastra lisan Lampung yang ada di } \\
\text { Desa Kunjir }\end{array}$ & - & 12 & 8 & 5 & - \\
\hline 9. & $\begin{array}{l}\text { Jarang sekali saya menyaksikan kegiatan sastra lisan } \\
\text { Lampung di Desa Kunjir }\end{array}$ & 4 & 16 & 5 & - & - \\
\hline 10. & $\begin{array}{l}\text { Saya menggemari sastra lisan Lampung yang ada di Desa } \\
\text { Kunjir }\end{array}$ & 5 & 13 & 4 & 3 & - \\
\hline 11. & $\begin{array}{l}\text { Muli Mekhanai memiliki peran untuk melestarikan sastra } \\
\text { lisan Lampung }\end{array}$ & 19 & 6 & - & - & - \\
\hline 12. & $\begin{array}{l}\text { Kegiatan Muli Mekhanai Desa Kunjir selalu berfokus pada } \\
\text { seni budaya Lampung }\end{array}$ & - & 9 & 9 & 7 & - \\
\hline 13. & $\begin{array}{l}\text { Saya terlibat aktif dalam berbagai kegiatan yang } \\
\text { dilaksanakan Muli Mekhanai Desa Kunjir }\end{array}$ & 5 & 15 & 3 & 2 & - \\
\hline 14. & $\begin{array}{l}\text { Kepengurusan Muli Mekhanai selalu aktif menyusun } \\
\text { program kerja dalam setiap tahunnya }\end{array}$ & 5 & 11 & 5 & 2 & 2 \\
\hline 15. & $\begin{array}{l}\text { Kegiatan Múli Mekhanai Desa Kunjir jarang menampilkan } \\
\text { seni pertunjukan sastra lisan Lampung }\end{array}$ & 2 & 7 & 3 & 10 & 3 \\
\hline 16. & $\begin{array}{l}\text { Para tokoh adat Desa Kunjir aktif memberikan masukan } \\
\text { dalam menyusun kegiatan Muli Mekhanai }\end{array}$ & 4 & 10 & 6 & - & - \\
\hline
\end{tabular}


17. Saya selalu menggunakan bahasa Lampung dalam komunikasi sehari hari

18. Orang tua saya menggunakan bahasa Lampung untuk berkomunikasi

19. Dalam berkomunikasi di lingkungan keluarga, saya terbiasa menggunakan bahasa Indonesia

20. Saya malu menggunakan bahasa Lampung di tempat umum

Keterangan:

SS : Sangat Setuju

$S$ : Setuju

RR : Ragu-ragu

TS : Tidak Setuju

STS : Sangat Tidak Setuju

Berdasarkan data angket di atas, diperoleh beberapa temuan dari muli mekhanai Desa Kunjir sebagai berikut.

1. masih memiliki kesadaran yang baik dengan menganggap sastra lisan Lampung merupakan hal yang sangat penting untuk mereka kuasai

2. seni budaya Lampung merupakan simbol jati diri

3. terdapat sebagian kecil yang masih menganggap bahwa pelestarian sastra lisan Lampung bukan menjadi tanggung jawab kalangan generasi muda. Kendati demikian, sebagian besar yang lain menyetujui bahwa mereka turut bertanggung jawab atas pelestarian sastra lisan Lampung khususnya di Desa Kunjir

4. memiliki kesadaran dengan menganggap mengenal sastra lisan Lampung merupakan sebuah keharusan bagi mereka sebagai generasi penerus

5. sebagian besar merasa malu menampilkan sastra lisan Lampung khususnya di depan umum. Hal tersebut akan menjadi hambatan tersendiri bagi perkembangan dan eksistensi sastra lisan Lampung di Desa Kunjir

6. sebagian kecil mereka yang masih tertarik dengan kesenian modern yang menjadi trend terkini dan sebagian besar yang lain menyetujui bahwa mereka tidak tertarik melihat kesenian modern yang menjadi trend terkini dan lebih tertarik dengan sastra lisan Lampung yang ada di Desa Kunjir

7. di lingkungan Desa Kunjir, seni budaya Lampung cenderung ke arah kurang digunakan oleh masyarakat penuturnya. Dari data tersebut juga tergambar bahwa eksistensi sastra lisan Lampung kurang mendapat tempat di lingkungan muli mekhanai sehingga intensitas pemakaiannya dirasa masih sangat jarang

8. sebagian kecil muli mekhanai kurang mengenal sastra lisan Lampung yang ada di Desa Kunjir dan sebagian besar lainnya masih mengenal dengan baik sastra lisan Lampung yang ada disana. Dengan demikian, eksistensi sastra lisan Lampung perlu lebih digiatkan dan disosialisasikan lagi terutama bagi muli mekhanai yang belum mengenal seni budayanya sendiri

9. sebagian besar muli mekhanai Desa Kunjir jarang sekali menyaksikan kegiatan sastra lisan Lampung di Desa Kunjir. Hal tersebut harus diperbaiki dengan cara menggiatkan kegiatan festival atau pagelaran seni lainnya dalam rangka mengenalkan seni budaya Lampung dalam bentuk seni pertunjukkan sastra lisan sehingga muli mekhanai Desa Kunjir akan lebih tertarik dengan seni budayanya sendiri.

10.sebagian besar muli mekhanai Desa Kunjir memiliki perilaku positif dengan adanya kegemaran dan ketertarikan mereka terhadap seni budaya Lampung yang ada di Desa Kunjir. Kendati demikian, terdapat sebagian kecil yang lain yang kurang menggemari seni budaya Lampung disana. Hal tersebut semestinya mampu dijadikan sebagai bahan evaluasi program-program seni budaya akan lebih menarik bagi muli mekhanai 
Desa Merak Batin

11.muli mekhanai memiliki peran untuk melestarikan sastra lisan Lampung. Hal tersebut merupakan representasi positif dari muli mekhanai yang memiliki peranan dalam melestarikan sastra lisan Lampung. Terlebih seluruh elemen tidak terkecuali muli mekhanai memiliki peranan dalam memajukan dan melestarikan seni budaya daerahnya

12.sebagian peserta yang menganggap bahwa kegiatan muli mekhanai Desa Kunjir selalu berfokus pada sastra lisan Lampung. Hal tersebut sudah menunjukkan komitmen dari muli mekhanai untuk terus melestarikan sastra lisan Lampung yang ada di Desa Kunjir. Akan tetapi sebagian peserta yang lain menganggap bahwa kegiatan muli mekhanai Desa Kunjir kurang berfokus pada sastra lisan Lampung

13.muli mekhanai Desa Kunjir memiliki perilaku positif dengan terlibat aktif dalam berbagai kegiatan dengan tujuan menghidupkan organisasi.

14.sebagian besar kepengurusan muli mekhanai diangap cukup aktif dalam menyusun program kerja setiap tahunnya dan roda organisasi muli mekhanai di Desa Kunjir berlangsung dengan baik

15.kegiatan muli mekhanai Desa Kunjir jarang menampilkan seni pertunjukan sastra lisan Lampung. Kendati demikian, sebagian kecil lainnya masih menganggap bahwa kegiatan muli mekhanai masih ada yang menampilkan pertunjukkan sastra lisan Lampung

16.terdapat sebagian besar peserta yang menganggap bahwa para tokoh adat Desa Kunjir aktif memberikan masukan dalam menyusun kegiatan muli mekhanai. Kendati demikian, sebagian kecil lainnya masih menganggap bahwa belum adanya peranan tokoh adat Desa Kunjir aktif memberikan masukan dalam menyusun kegiatan muli mekhanai. Hal tersebut harus menjadi catatan perbaikan bagi para tokoh adat di Desa Kunjir agar lebih terlibat aktif dalam memberikan sumbangsih pemikiran

17.sebagian besar peserta selalu menggunakan bahasa Lampung dalam komunikasi sehari hari. Kendati demikian, sebagian kecil lainnya masih ragu-ragu dalam menggunakan bahasa Lampung untuk berkomunikasi

18.terdapat sebagian besar peserta yang orang tuanya menggunakan bahasa Lampung untuk berkomunikasi. Hal tersebut menunjukkan prilaku pola asuh yang baik dengan tetap menggunakan bahasa Lampung sebagai komunikasi di lingkungan keluarga

19.sebagian besar peserta terbiasa menggunakan bahasa Indonesia dalam berkomunikasi di lingkungan keluarga. Hal tersebut menunjukkan bahwa bahasa Lampung hanya digunakan oleh orang tua dan tidak digunakan oleh anak sebagai generasi muda. Akan tetapi, sebagian yang lain tetap memilih menggunakan bahasa Lampung sebagai bahasa komunikasi di lingkungan keluarga

20.sebagian besar peserta tidak malu menggunakan bahasa Lampung di tempat umum dan tetap percaya diri menggunakannya meski di tengah keramaian.

Selain dari data angket materi, tim pengabdian juga menyebarkan angket evaluasi kegiatan pengabdian kepada masyarakat, sebagai berikut.

Tabel 3. Angket Evaluasi Penyelenggaraan Kegiatan

\begin{tabular}{|c|c|c|c|c|c|c|}
\hline No. & PERNYATAAN & SS & $\mathbf{S}$ & $\mathbf{R} \mathbf{R}$ & TS & STS \\
\hline 1. & Materi yang disampaikan menarik & 17 & 8 & - & - & - \\
\hline 2. & $\begin{array}{l}\text { Materi yang diberikan bermanfaat untuk Muli } \\
\text { Mekhanai Desa Kunjir }\end{array}$ & 16 & 9 & - & - & - \\
\hline 3. & Pemateri komunikatif dalam menyajikan materi & 13 & 12 & - & - & - \\
\hline 4. & Bahasa yang digunakan pemateri mudah dipahami & 15 & 10 & - & - & - \\
\hline 5. & $\begin{array}{l}\text { Ketepatan waktu penyelenggaran telah sesuai } \\
\text { rundown }\end{array}$ & 9 & 13 & 3 & - & - \\
\hline
\end{tabular}




$\begin{array}{lllllll}\text { 6. } & \text { Lokasi pengabdian telah memadai } & 9 & 16 & - & - & - \\ \text { 7. } & \text { Fasilitas pendukung kegiatan tersedia dengan baik } & 16 & 9 & - & - & - \\ \text { 8. } & \text { Layanan konsumsi tersedia dengan baik } & 19 & 6 & - & - & - \\ \text { 9. } \begin{array}{l}\text { Kegiatan pengabdian telah sesuai dengan protokol } \\ \text { pencegahan penyebaran Covid-19 }\end{array} & 18 & 7 & - & - & - \\ \end{array}$

Keterangan:

SS : Sangat Setuju

$S$ : Setuju

RR : Ragu-ragu

TS : Tidak Setuju

STS : Sangat Tidak Setuju

Berdasarkan angket evaluasi kegiatan di atas, kegiatan pengabdian yang diikuti oleh seluruh peserta berjalan dengan baik. Terbukti dengan penilaian angket yang telah dibagikan kepada peserta, angket evaluasi yang pertama berkaitan dengan materi yang disampaikan oleh masing-masing pemateri. Selain itu, materi yang disampaikan oleh pemateri memberikan dampak dan manfaat bagi mereka terutama bagi muli mekhanai Desa Kunjir.

Berkaitan dengan apakah pemateri komunikatif dalam menyajikan materi. Hasil angket menunjukkan bahwa masing-masing pemateri ketika dalam menyajikan materi sangat komunikatif menarik minat peserta kegiatan pengabdian ini. Kemudian sebagian besar materi-materi yang disampaikan oleh pemateri mudah dipahami dan dicerna dengan baik oleh peserta kegiatan. Selanjutnya terkait dengan waktu kegiatan sudah berjalan sebagaimana jadwal yang telah disepakati sebelumnya. Kendati demikian pada hari pertama pembukaan, waktu berjalan tidak sesuai dengan jadwal yang ada dikarenakan beberapa hal, seperti kedatangan pemateri dan peserta yang tidak tepat waktu.

Peserta kegiatan pelatihan ini menyatakan bahwa tempat yang disediakan cukup memadai termasuk fasilitas yang disediakan oleh panitia cukup baik dan memadai meskipun ada beberapa perbaikan yang semestinya diperbaiki. Berkaitan dengan pelayanan konsumsi, peserta menyatakan pelayanan konsumsi tersedia dengan baik. Selanjutnya berkaitan dengan kegiatan pengabdian apakah telah sesuai dengan protokol pencegahan penyebaran Covid-19. Hasil angket menunjukkan bahwa kegiatan pelatihan pengabdian ini telah melaksanakan protokol kesehatan yang sesuai dengan aturan pemerintah.

Beradasarkan jabaran hasil analisis data angket di atas, dapat disimpulkan bhawa pelaksanaan kegiatan pengabdian ini diterima dengan baik oleh peserta kegiatan baik dalam hal materi yang disajikan oleh pemateri, fasilitas yang disediakan, layanan konsumsi, dan penerapan protokol kesehatan berjalan dengan baik. Namun dalam hal ketepatan waktu kegiatan perlu adanya evaluasi, agar kegiatan yang akan dilaksanakan selanjutnya dapat berjalan dengan baik dan sesuai dengan jadwal yang dirancang sebelumnya. 


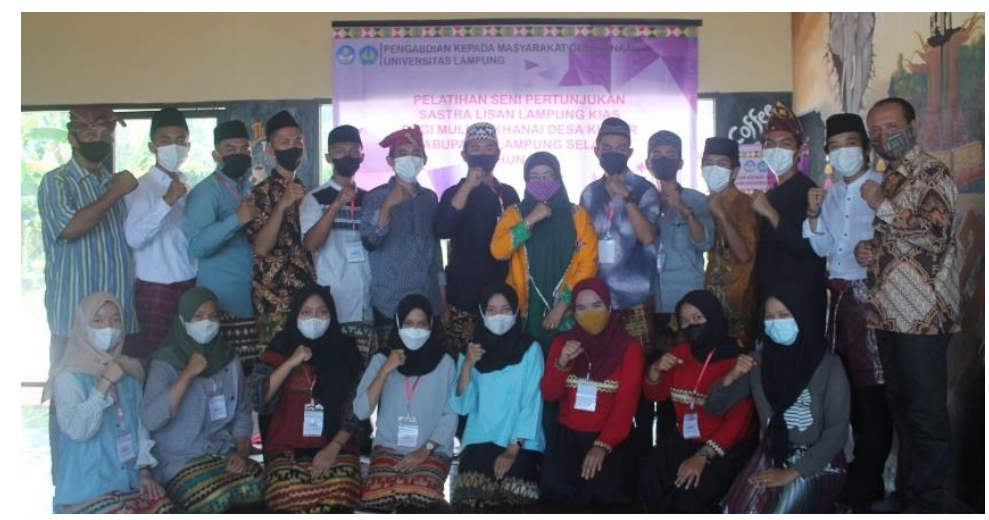

Gambar 6. Sesi Foto Bersama Seluruh Peserta

\section{KESIMPULAN DAN SARAN}

\section{Kesimpulan}

Pelatihan ini telah mencapai tujuan dan sasaran yaitu dapat memberi pengetahuan dan keterampilan kepada muli mekhanai Desa Kunjir tentang pentingnya mengolah, mengembangkan, dan mengekspresikan sebuah sajian sastra lisan Lampung Kias menjadi seni pertunjukan yang menarik. Luaran yang ingin dicapai dalam kegiatan ini, yaitu peningkatan pemahaman dan kompetensi dalam menyajikan sebuah seni pertunjukan sastra lisan Lampung Kias bagi muli mekhanai Desa Kunjir Kabupaten Lampung Selatan. Pada umumnya, para peserta yang mengikuti pelatihan ini merasakan perbedaan antara sebelum dan sesudah mengikuti pelatihan ini. Dengan demikian, dapat disimpulkan bahwa muli mekhanai peserta pelatihan ini merasakan manfaat yang besar setelah mengikuti pelatihan ini.

\section{Saran}

Setelah pelatihan ini, muli mekhanai diharapkan dapat terus mengembangkan dan mampu menjadi garda terdepan dalam rangka pengembangan dan pelestarian sastra lisan Lampung Kias sehingga dapat diteruskan dari generasi ke generasi. Selain itu, pelatihan seperti ini juga sebaiknya dilakukan secara berkesinambungan karena berdampak luar biasa kepada muli mekhanai sebagai peserta pelatihan. Selain mendapatkan pengetahuan baru, mereka juga merasa sangat termotivasi.

\section{UCAPAN TERIMA KASIH}

Terima kasih disampaikan kepada LPPM Universitas Lampung yang telah mendanai kegiatan Pengabdian kepada Masyarakat ini. Juga kepada seluruh mitra pengabdian dan tim yang terlibat.

\section{DAFTAR PUSTAKA}

[1] Armina. (2013). Pantun Kias dalam Masyarakat Lampung Barat (Kajian Etnografi). (Disertasi). Jakarta: Universitas Negeri Jakarta.

[2] Armina. (2013). Kias Sastra Lisan Masyarakat Lampung Barat (Kajian Etnografi). Yogyakarta: Fahma Media.

[3] Sanusi, A.E. (1990). Sastra Lisan Lampung. Lampung: Unila. 
